\title{
Additional Archaeological Survey In The Dry Comal Watershed, Comal County, South Central Texas
}

\author{
Thomas C. Kelly \\ Thomas R. Hester \\ Center for Archaeological Research
}

Follow this and additional works at: https://scholarworks.sfasu.edu/ita

Part of the American Material Culture Commons, Archaeological Anthropology Commons, Environmental Studies Commons, Other American Studies Commons, Other Arts and Humanities Commons, Other History of Art, Architecture, and Archaeology Commons, and the United States History Commons

Tell us how this article helped you.

This Article is brought to you for free and open access by the Center for Regional Heritage Research at SFA ScholarWorks. It has been accepted for inclusion in Index of Texas Archaeology: Open Access Gray Literature from the Lone Star State by an authorized editor of SFA ScholarWorks. For more information, please contact cdsscholarworks@sfasu.edu. 
Additional Archaeological Survey In The Dry Comal Watershed, Comal County, South Central Texas

\section{Creative Commons License}

(c) (1) (5)

This work is licensed under a Creative Commons Attribution-NonCommercial 4.0 International License 


\section{Additional Archaeological Survey In The Iry Comal Watershed, Comal County, South Central Texas}

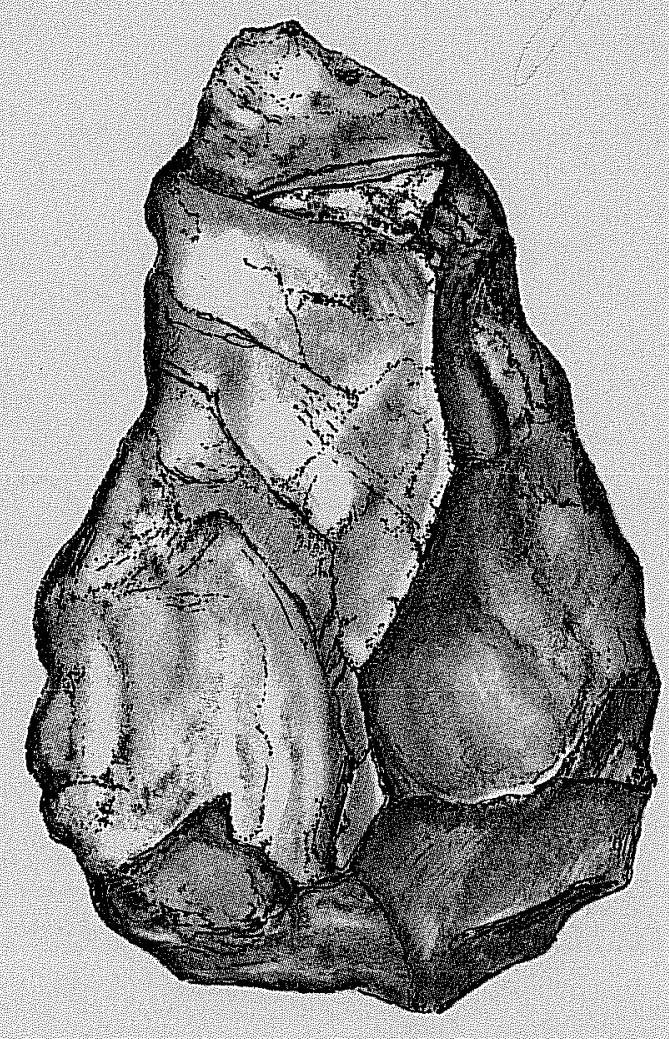

THOMAS C. KEIIY and THOMAS R. HESTER

Center for Archaeological Research The University of Texas at San Antonio Archaeological Survey Report, No. 10

1975

UTSA - Center TOTi

Arehaeological Research 
ADDITIONAL ARCHAEOLOGICAL SURVEY IN THE DRY COMAL WATERSHED, COMAL COUNTY, SOUTH CENTRAL TEXAS

Thomas C. Kelly and Thomas R. Hester

Center for Archaeological Research The University of Texas at San Antonio Archaeological Survey Report, No. 10

June 1975 
TABLE OF CONTENTS

Page

Introduction

1

The Survey

1

Lithic Resources

Results of the Intensive Survey

Summary

25

Recommendations

27

References Cited

29 


\section{FIGURES}

1. Locations of Archaeological Sites in the Vicinity of Floodwater Retarding Structure No. 1, West Fork, Dry Comal Creek.

2. Distribution of Lithic Materials at Certain Sites in the Vicinity of Floodwater Retarding Structure No. 1 .

3. Archaeological Sites in Floodwater Retarding Structure No. 1 .

4. Lithic Artifacts from Sites in the Vicinity of Floodwater Retarding Structure No. 1.

TABLE

1. 41 CM 84: Artifacts from Test Pit 


\section{INTRODUCTION}

In April, 1975, an intensive archaeological survey was carried out in the area proposed for the construction of Floodwater Retarding Structure No. 1, located on the West Fork of Dry Coma1 Creek, in Comal County, south central Texas (see Fig. 1). The survey was conducted in terms of an agreement (1339-TX-SCS-75) between the U.S.D.A. Soil Conservation Service and the Center for Archaeological Research, The University of Texas at San Antonio. An initial reconnaissance of the area was conducted by Center personnel in November, 1974 and six archaeological sites were located (Hester, Bass and Kelly 1975). However, it was recognized that a more thorough survey would be required in order to fully appraise the archaeological resources at the locality. Therefore, an intensive survey was recommended in the published report of the 1974 investigations (Hester, Bass and Kelly 1975: 22-23).

The reader is referred to Hester, Bass and Kelly (1975) for a discussion of previous archaeological research in Comal County. A description of the Floodwater Retarding Structure No. 1 vicinity is also provided in that report. The dam site, and the sediment, flood, and detention pools, will encompass an area of approximately 276 acres (112 hectares).

\section{THE SURVEY}

The intensive examination of the Floodwater Retarding Structure No. 1 locality was conducted under the supervision of Dr. Thomas 
Figure 1. Locations of Archaeological Sites in the Vicinity of Floodwater Retarding Structure No. 1, West Fork, Dry Comal Creek. The 900-foot (274-meter) contour is shown. Note also the position of planned borrow areas. 
This page has been

redacted because it

contains restricted

information. 
R. Hester. Members of the field team were Thomas C. Kelly and Lynn Highley, aided by James Warren, archaeologist for the Soil Conservation Service. During the course of the survey, an effort was made to reach as many portions of the proposed reservoir as possible. Although dense vegetation made inspection of some areas impossible, we were able to document 18 additional archaeological sites. Sites 41 CM 57 and 41 CM 58, recorded during the 1974 survey, were rechecked. Brief test excavations were conducted at site $41 \mathrm{CM} 84$.

Site survey forms were completed for all of the new sites and their locations were plotted on the U.S.G.S. Bat Cave quadrangle. All notes and artifacts resulting from the intensive survey are on file at the Center for Archaeological Research.

\section{LITHIC RESOURCES}

Lithic materials are abundant at most of the sites documented at Floodwater Retarding Structure No. 1. It was soon noted by the survey team that some of the sites contained only one type of chert, while others contained another type or several different kinds of chert. Collections from the sites were examined and three major types of chert were discerned. These have been designated as classes A, B, and C. The distribution of lithic materials is shown in Fig. 2 .

Class A chert is a fine-grained, dark honey-colored, homogeneous chert, translucent in thin sections. Class B also has a dark honey color, but is opaque and has some intrusions. It is still a good quality chert, knapping almost as well as Class A materials in experiments conducted by the senior author. Class $C$ is a buff-colored, 
Figure 2. Distribution of Lithic Materials at Certain Sites in the Vicinity of Floodwater Retarding Structure No 1. Site numbers are shown in Figure 1. The letters $A, B, C$, denote the presence of artifacts of these classes of chert. The letter $\mathrm{L}$ indicates the occurrence of siliceous limestone artifacts. 
This page has been

redacted because it

contains restricted

information. 
opaque chert, with frequent dark intrusions. Experimentally, it is more difficult to flake, and the resulting artifacts are generally more crude than those produced using the better cherts (Classes A, B). In several sites, Class $\mathrm{C}$ chert has apparently been heat-treated; specimens often have a light pink color and a glossy sheen (cf. Hester and Collins 1974).

At one site, $41 \mathrm{CM} 84$, pieces of siliceous limestone were used for hammerstones. This material is gray-white and contains chert intrusions. Experiments reveal that it can be knapped, although with considerable difficulty. However, the only artifacts made of this material were found at site 41 CM 84 .

Chert of Classes $A, B$, and $C$ apparently occur in nodular form, weathered out of limestone exposures in the vicinity. Discrete sources of the material have not been recognized; most likely, there are several outcrops which yield these cherts.

\section{RESULTS OF THE INTENSIVE SURVEY}

Eighteen archaeological sites were documented during the course of the intensive survey of Floodwater Retarding Structure No. 1. Locations of these sites, as well as those found in the initial survey in 1974 (Hester, Bass and Kelly 1975), are shown in Fig. 1. Detailed locational data are on file at the Center for Archaeological Research, and this information has been made available to the Soil Conservation Service.

Intensive survey was mainly confined to the area within the 900-foot (274-meter) contour (see Fig. 1), as this contour formed the boundary of the detention pool. Close attention was also given to the centerline 
of the proposed dam and to planned borrow pit areas (see Fig. 1). Sites lying just outside the SCS project were also recorded, and data obtained from the examination of these sites are provided here.

$41 \mathrm{CM} 71$

The site is located in the spillway area at the west end of the proposed dam. An area roughly 15 meters in diameter contained several hundred pieces of fine-grained, honey-colored chert (Class A) knapping debris, scrapers, utilized flakes, choppers or cleavers, and a few thin biface preforms. All preforms had been broken in the manufacturing process (often as a result of hinge fractures) or had developed manufacturing flaws preventing their further thinning (in many instances, there were well developed "knots" with repeated step fractures representing unsuccessful removal attempts).

Shovel and trowel tests were made to a depth of $20 \mathrm{~cm}$ but nothing was found below $10 \mathrm{~cm}$. This site was located in a thicket of oak trees and dense underbrush and had just been uncovered by roads bulldozed to permit core drilling and pit-testing of the area by SCS geologists. Thus, the complete absence of dart points and fragments cannot be attributed to collector activities as it can in some areas of the survey.

The geological team later bulldozed a large pit on the site, providing an excellent cross-section. Humus and clay deposits $20-35 \mathrm{~cm}$ thick overlay a white limestone (to a depth of six meters) with large nodules of fine-grained Class A chert randomly scattered throughout. 
These nodules, eroding from surface exposures of the limestone formation, provided the raw material for the artifacts in this site.

$41 \mathrm{CM} 72$

This site is also in the spillway area approximately 180 meters northwest of CM 71. An irregular area of approximately $150 \times 200$ meters is fairly open with patches of oak, elm, and cedar. Mrs. Krause, the wife of a local landowner, showed us this site. She has picked up a number of very large quarry blanks in this area over a number of years. The largest measures $260 \times 184 \times 29 \mathrm{~cm}$, weighs several kilograms, and is made of Class A chert. There is wear on the distal end which suggests that it was heavily used as a chopping tool. The survey crew found three large quarry blanks, two broken billet-flaked preforms, three fist-sized chopping tools with heavily battered edges, and considerable knapping debitage. The three quarry blanks all had concave scraper edges battered by heavy use. All artifacts were of Class A chert. Only one small area of fire-blackened limestone was observed, and it was the opinion of the survey crew that it was post-aboriginal in origin, possibly associated with a nearby deer blind.

$41 \mathrm{CM} 73$

The site is located in an old stream bed 290 meters upstream (northwest) from the dam centerline. The present stream channel is approximately 50 meters to the west, but during high water this is flooded. The site is of indeterminate size, being exposed by a bulldozed opening in an otherwise impenetrable cedar thicket. Fourteen 
artifacts were collected from a 20 x 30 meter area cleared by an SCS core-drilling crew. The survey team was of the opinion that the artifacts were derived from upstream as some show stream-rolled wear, and there were no associated small flakes or debitage.

Artifacts consisted of two unifacial choppers or cleavers, two broken bifacial preforms, five large, thick flake cutting/chopping tools, two large flake cutting tools with concave scraper edges and one bifacial tool with a concave scraping edge. The two preforms were of Class A chert with the rest of the artifacts being made from class $C$ material. Several of the Class C specimens were possibly heat treated as indicated by a pink tinge to the chert.

\section{$41 \mathrm{CM} 74$}

The site lies in dense cedar flats east of the stream bed and approximately 650 meters upstream from CM 73. The site covers an area of approximately three meters in diameter and was surveyed on hands and knees while trying to get in (and out) of the cedar thicket. The artifacts consisted of a partially buried cache of five very large quarry blanks of Class A chert, and nearby, two small bifacial preforms (Class B chert), a core rejuvenation flake showing secondary heavy scrapping use, a flake scraper, and several large flakes. The large quarry blanks were lying parallel on their edges a few centimeters apart. Only the smallest one was collected and it measures $20.5 \times 13.7$ $\mathrm{x} 6.8 \mathrm{~cm}$ and exhibited one heavily worn concave scraper edge on one side. 
$41 \mathrm{CM} 75$

The site is 900 meters northwest of the west end of the proposed dam, and 180 meters east of a ranch road; it is situated on a flat area that gently slopes east toward steep bluffs above the creek. An area 10 meters in diameter was strewn with knapping debris, several large primary (cortex) flakes and two crude bifaces representing an intermediate stage of preform manufacture. All were of Class C chert. The site was between the 950-foot (290-meter) and 960-foot (293-meter) contour levels, and therefore out of the detention pool. No artifacts were collected.

\section{CM 76}

The site covers an area approximately 15 meters in diameter, and is located on a slight knoll 500 meters north of CM 75. Broken chert cobbles, two crude bifaces, one concave scraper on a thick large flake, and knapping debris were observed but not collected. This site is out of the detention and flood pools. The chert at the site was of Class C material.

\section{$41 \mathrm{CM} 77$}

The site is located on a fairly open, flat bench on the high ground between the fork made by a tributary (originating 2.3 kilometers to the northwest) and the West Fork of Dry Comal Creek. The site is approximately 290 meters east-southeast of the Rigsby windmill (see Fig. 1) and is completely surrounded by a heavy stand of oak, elm and cedar. The soil is red clay. Collected artifacts consisted of four large cleaver/choppers, three crude quarry blanks, 14 large flakes (all with resharpened cutting edges), 15 thinning flakes 
and 11 pieces of miscellaneous debitage. The site was approximately 20 meters in diameter. All of the chert was of Class $C$, with several pieces thermally-altered from buff to pink. A majority of the artifacts were also covered with a greasy black stain similar to that often seen in burned rock middens. Scattered burned limestone was observed but there were no discernable hearths or accumulations.

\section{$41 \mathrm{CM} 78$}

The site is located 180 meters southeast of CM 77 on a gentle slope east of the creek. It is very similar to CM 77, with the presence of Class $\mathrm{C}$ chert (often thermally altered, and deeply patinated). A few burned limestone rocks were observed. The collected artifacts consisted of one large unifacially trimmed flake, one broken quarry blank with an apparent chopper/cleaver edge, two large primary flake cutting tools, two quarry blanks with no worn or used surfaces, two large secondary flake cutting tools with heavily worn concave scraper edges, and two small trimmed flakes.

\section{CM 79}

The site is located 780 meters due east of the Rigsby windmill in a flat open area roughly 60 meters in diameter (Fig. 1). The soil is reddish clay with five large, flat limestone boulders rising $10-20 \mathrm{~cm}$ above the thin soil. Fifteen artifacts were clustered around these boulders. They were located and mapped in situ and numbered as picked up. From the cluster pattern it seems likely that the artifacts were associated with the boulders which probably served as working areas (and possibly anvils) for the aboriginal knappers . 
we do not believe that any important archaeological information will be lost as a result. The other sites are either at the upper end of the reservoir or at higher elevations. We do not think that these will be seriously disturbed as a result of development of the floodwater retarding structure.

None of the sites in the vicinity of Floodwater Retarding Structure No. 1 are to be recommended to the National Register of Historic Places. While these sites, like all archaeological resources, are deemed by us to be important, we are of the opinion that they are not appropriate for placement on this national listing.

\section{REFERENCES CITED}

Hester, T. R., F. A. Bass, Jr., and T. C. Kelly

1975 Archaeological Survey of Portions of the Comal River Watershed, Comal County, Texas. Center for Archaeological Research, University of Texas at San Antonio, Archaeological Survey Report 6.

Hester, T. R. and M. B. Collins

1974 Evidence for Heat Treating of Southern Texas Projectile Points. Bulletin of the Texas Archeological Society 45: 219-224. 
